\title{
DIATOM ASSEMBLAGES IN SURFACE SEDIMENTS AND THEIR REFLECTION ON THE WATER MIGRATION PATHWAY FROM THE INSHORE WATERS OF WESTERN BOHAI BAY, CHINA
}

\author{
LI, Y. ${ }^{1}$ - FANG, J. ${ }^{1 *}-$ TIAN, L. Z. $.^{2,3 *}-$ WANG, F. ${ }^{2,3}-$ CHEN, Y. S. ${ }^{2,3}$ \\ ${ }^{1}$ School of Geography and Environmental Science, Tianjin Normal University \\ 300387 Tianjin, China \\ ${ }^{2}$ Tianjin Centre, China Geological Survey, 300170 Tianjin, China \\ ${ }^{3}$ Key Laboratory of Coast Geo-environment, China Geological Survey, 300000 Tianjin, China \\ ${ }^{*}$ Corresponding authors \\ e-mail:jq19066818jingxi@163.com (Fang, J.); lzrd1682340q@163.com (Tian, L. Z.) \\ (Received $17^{\text {th }}$ Sep 2019; accepted $8^{\text {th }}$ Jan 2020)
}

\begin{abstract}
One hundred and twenty-six surface diatom samples were analysed to investigate the characteristics of their assemblages and the seawater migration pathway from the inshore waters of the western Bohai Bay. For this task we used correspondence analysis (CA) and discussed the seawater pathway according to the distribution of freshwater diatoms and their abundance. Result shows that a total of 49 species and 32 genera are identified, of which Cosinodiscus excentricus, Cosinodiscus radiatus, Actinocyclus normanii and Cyclotella stylorums are the dominant species. The study area is divided into four diatom combination zones. The freshwater diatoms are regularly distributed in the study area and range from $0.48 \%-13.13 \%$. In the waters south of the Duliujian River estuary, the proportion of freshwater diatoms decreases from south to north, indicating that the water currents tend to move in the same direction. In the southeastern sea area of the Lingang Economic Zone, due to land reclamation and hydrodynamic condition changes, freshwater diatoms are deposited. In the bay north of the Haihe River estuary, coastal currents are characterized by a clockwise circulation.
\end{abstract}

Keywords: surface diatom, CA analysis, pathway of currents, sedimentary environment

\section{Introduction}

Bohai Bay is located on the west bank of the Bohai Sea and is a typical semi-closed bay slope; thus, the water exchange capacity is inadequate. After many coastal rivers merge into the inshore waters of the western Bohai Bay, terrigenous sediments have trouble moving to the middle of the Bohai Sea or to the open sea. The coastal land reclamation project along the Bohai Bay has affected the hydrodynamic conditions and ecological environment of the coastal waters ( $\mathrm{Tu}$ et al., 2017). Four hundred and thirty-two species of plankton have been identified in the Bohai Sea, of which diatoms are the dominant species ( $\mathrm{Li}$ and Tao, 2000). Diatoms are sensitive to environmental changes and are affected by temperature, salinity, eutrophication, and fluid dynamics (Hendey and Part, 1964; Leroy et al., 2018). Many scholars have studied the ecological and geographical distribution of diatom species and their relationship with the sedimentary environment, but the characteristics of surface diatoms and the formation of diatom combinations vary between regions (Karpuz and Schrader, 1990; Cunningham and Leventer, 1998; Artemova, 2018).

Worldwide, research on surface diatoms in seas has been extensive. Cárdenasa et al. (2019) studied the way diatoms, bulk sediment composition and geochemical proxies 
respond to oceanic domains and polar to subpolar frontal systems in surface sediments across the Drake Passage. Results show the relevance concerning the composition of surface sediments and ocean productivity, terrigenous input, the intensity of ocean currents, and ice proximity. Weckström and Juggins (2006) explored the relationship between surface sediment diatom assemblages and 15 environmental variables for providing potential means for quality assessments of coastal waters in the Gulf of Finland. In the Canary region, Modern diatom and $\mathrm{C}_{\text {org }}$ distribution patterns were investigated to quantitatively determine the influence of coastal upwelling and Saharan dust on the flux of sedimentary components (Nave et al., 2001). Hay et al. (2003) used the distribution patterns of diatom microflora in the Effingham Inlet off the west coast of Vancouver Island to determine the impact of coastal oceans on the interior of the Effingham Inlet Fjord. Perez et al. (2018) researched environmental gradients associated with the freshwater input and oceanic water intrusion of the Río de la Plata estuary (RdlP), and assessed diatom species distribution in surface sediment samples related to such environmental gradients. Researchers also investigated the distribution and combination of diatom in the surface sediments of the South China Sea and revealed the sedimentary environment and hydrodynamic changes in the sea; diatom combination are of great significance for tracking water currents and water masses (Ran and Jiang, 2005; Wu et al., 2013). Chen et al. (2019) determined the variation of the distribution of diatoms in surface sediments on the inner shelf of the East China Sea affected by season and typhoon. As for the East China Sea and the Yellow Sea, diatom combinations, as well as their impact on the environment have also been studied (Chen et al., 2000; Wang et al., 2001, 2009). However, at present, most diatom research concerning the Bohai Bay involves sea areas of >10 m isobaths (Shang et al., 2006; Liu et al., 2015). As for the inshore waters of the western Bohai Bay, Shang et al. (2012) studied surface sedimentary diatoms in the intertidal zone and adjacent sea areas, revealing that salinity and depth are essential factors controlling the distribution of diatoms.

Due to the low proportion of freshwater diatoms in Bohai Bay, the study of surface diatoms in that area has mainly concentrated on saltwater and brackish water diatoms, while few studies have been performed on freshwater diatoms (Chen et al., 2014; Xu et al., 2017; Pan et al., 2019). On the western coast of the Bohai Bay, many rivers are developing, thus freshwater diatoms inhabiting freshwater systems are often carried into the sea by those rivers, moving under the influence of tide and currents. The Bohai Bay is Semi-closed, and thus, the freshwater diatoms entering the sea impacts on the diatom species in the sea.

In recent years, large-scale coastal land reclamation projects along the Bohai Bay have changed the original coastline and affected the distribution of diatoms in the sea. Therefore, 126 surface samples were collected from the inshore waters of the western Bohai Bay for diatom identification and analysis. We analysed the characteristics of diatom combinations using correspondence analysis (CA) in the study sea area. Besides, we discussed the seawater pathway in the inshore waters of the western Bohai Bay according to the distribution of freshwater diatoms and their abundance.

\section{Study area}

The study area is located in the inshore waters of the western Bohai Bay, China (Fig. 1). The water depth ranges from 1 to $10 \mathrm{~m}$ in the isobath. Seabed topography tiltes from east to west and the slope is relatively low and flat. There are four types of sediments in the area, including sand, silty sand, sandy silt, and clay silt. The distribution of silt is the most extensive. The particle size has a distribution trend that gradually tapers from north to south and from inshore to offshore (Institute of Marine 
Geology, Institute of Oceanology, Chinese Academy of Sciences, 1985; Tian et al., 2010; Ding et al., 2019). As a semi-closed inland sea, water temperature, salinity, and other factors are mainly affected by season and freshwater injections (Institute of Marine Geology, Institute of Oceanology, Chinese Academy of Sciences, 1985). The hydrodynamics in the sea are mainly affected by tides, currents, and waves. The current is affected by the warm Yellow Sea current, and the coastal current (Zhao et al., 1995). The study area is adjacent to the lowland plains, and the elevation is generally below 3 $\mathrm{m}$. There are many rivers on the plains that terminate in the sea. From north to south, such rivers include the Jian River, the Jiyun River, the Chaobaixin River, the Yongdingxin River, the Haihe River, the Duliujian River, the Ziyaxin River, and the Shibei River. Most of those rivers are seasonal or sewage rivers, carrying sediment into the sea, and thus, providing a source of sediment. In recent years, land reclamation on the west coast of the Bohai Bay has destroyed the original natural coastline (Wang et al., 2010), which has complicated the current and tide in the region.

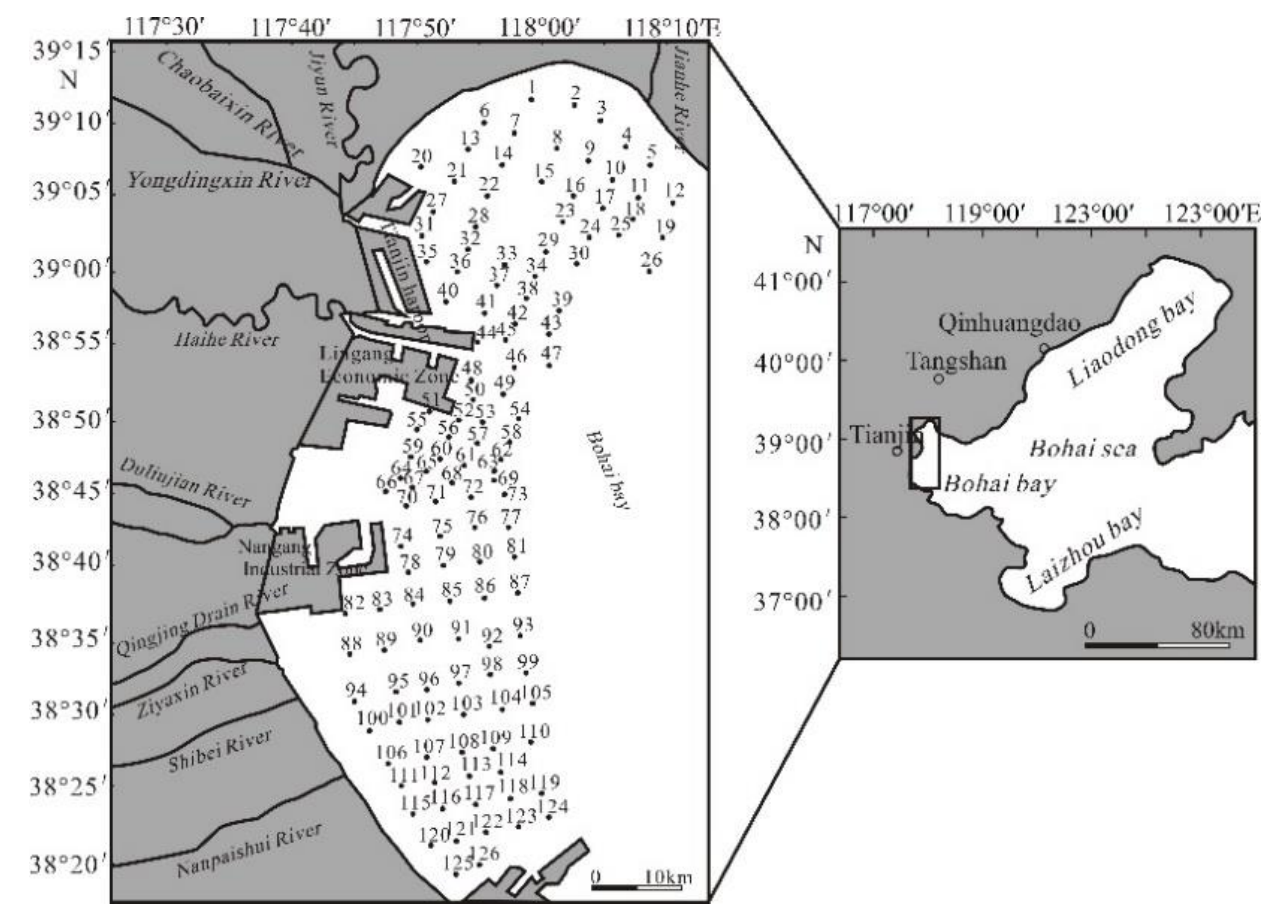

Figure 1. Sampling sites in the inshore waters of the western Bohai Bay

\section{Materials and methods}

One hundred and twenty-six surface diatom samples were obtained by the Tianjin Center of the China Geological Survey in August 2017 from the inshore waters of the western Bohai Bay $\left(38^{\circ} 21^{\prime} \mathrm{N}-39^{\circ} 10^{\prime \prime} \mathrm{N}, 117^{\circ} 39^{\prime \prime}\right.$ E-118 11 'E) (Fig. 1). Samples were taken with grab or box corer. The top sediments were prepared for diatom analysis according to Renberg (1990) and Smol et al. (2001). Preparation was proceeded as follows: $1 \mathrm{~g}$ dry sample was weighed into a $250 \mathrm{~mL}$ flask and treated with $10 \% \mathrm{HCl}$ overnight to remove carbonates. Then, samples were treated with $30 \% \mathrm{H}_{2} \mathrm{O}_{2}$ for $24 \mathrm{~h}$ to remove organic material. Next, flasks were incubated with $250 \mathrm{~mL}$ distilled water for $24 \mathrm{~h}$ to disperse the clay material. The supernatant was then decanted after at least $24 \mathrm{~h}$. The above steps were repeated 3-4 times. Subsequently, samples were adjusted to a 
volume of $50 \mathrm{~mL}$, and $0.5 \mathrm{~mL}$ of the solution was dripped onto a coverslip on a hot plate. After drying, the coverslip was placed on a glass slide coated with a neutral balsam to prepare diatom flakes. Approximately 3-4 flakes were generated per sample. Counting was performed with a Nikon 53-1 Nikon optical microscope at 400x magnification and photographed with a Nikon imaging system. For surface sediments, at least 500 diatom valves were enumerated. The absolute abundance of diatoms per station was calculated.

CA was used to analyse the characteristics of diatom assemblages using canoco4.5 software. Due to the low abundance of some diatom species, species appeared in at least two sediment samples and had a proportion of more than $1 \%$ in at least one sample were selected for analysis (Bennion, 1994; Hall and Smol, 2010).

\section{Results}

\section{Diatom identification}

One hundred and twenty-six surface sediment samples were analysed from the study area. A total of 49 species and varieties of diatoms from 32 genera are identified (Fig. 2). Saltwater diatoms mainly include Cosinodiscus excentricus and Cosinodiscus radiates, but also include Actinocyclus normanii, Dictyocha fibula, Cyclotella striata, Cyclotella stylorum, Thalassiosira nizschioides, Paralla sulcata, Trachyneis aspera, Actinoptychus senarius, Surirella fluminensis, Triceratium favus, Eucampia Zoodiacus, Nitzschia kerguelensis and Navicula clementis. Brackish water diatoms are mainly Diploneis bombus and Nitzschia granulata, but also include Auliscus caelatus, Diploneis suborbicularis, Diploneis smithii, Nitzschia compressa, Rhaphoneis surirella, Rhaphoneis amphicero, Tryblioptychus cocconeiformi, Rhopalodia gibberula, Grammatophora macilenta, Opephora martyi, Navicula marina, Actinoptychus annulatus, Rhizosolenia imbricate, Nitzschia lorenziana and Dimeregramma minor. Freshwater diatoms are found in low abundance in 93 stations, including Achnanthes hauckiana, Synedra tabulata, Epithemia adanata, Pleurosigma normanii, Pinnularia nobils, Hantzschia amphioxys, Navicula radiosa, Nitzschia gracilis, Gomphonema tumidum, Melosira granulata, Nizschia amplectems, Synedra ulna, Nitzschia palea, Rhopalodia gibba, Ellerbeckia arenaria, Eunotia valida and Gyrosigma acuminatum.

The dominant diatom species that can reflect the characteristics of the community, and control the community structure were determined according to the formula of Shen and Shi (2002), shown as Formula (1):

$$
\mathrm{Y}=\mathrm{n}_{1} * \mathrm{f}_{1} / \mathrm{N}
$$

where $n_{i}$ is the number of individuals of all species, $f_{i}$ is the frequency of a given species in each sample, and $\mathrm{N}$ is the total number of individuals counted for each sample. A Y value $>0.02$ indicates a dominant species.

According to the calculations, four dominant species are found, and all of which are saltwater species, including Cosinodiscus excentricus, Cosinodiscus radiatus, Actinocyclus normanii and Cyclotella stylorums. Among those species, Cyclotella stylorums is a dominant species from the Duliujian River estuary to the Nanpaishui River estuary, whereas its abundance in other sea areas is low. 


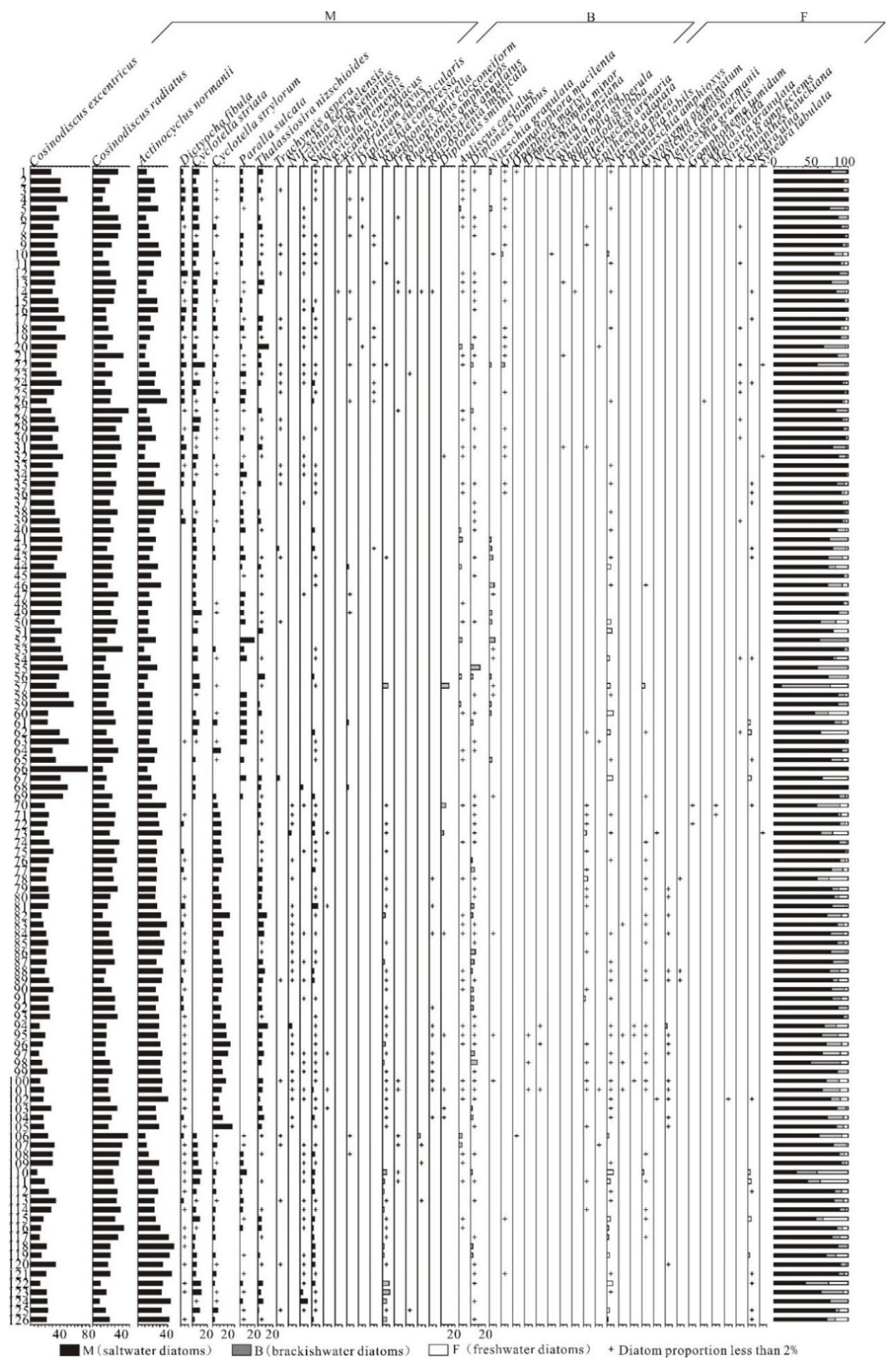

Figure 2. Species of diatoms in the study area 


$$
-2184 \text { - }
$$

\section{The distribution of diatoms}

The distribution profiles were plotted using ARCGIS (ARCGIS version 10.2) according to the diatoms abundance, percentage of saltwater, brackish, and freshwater species at each station (Fig. 3).

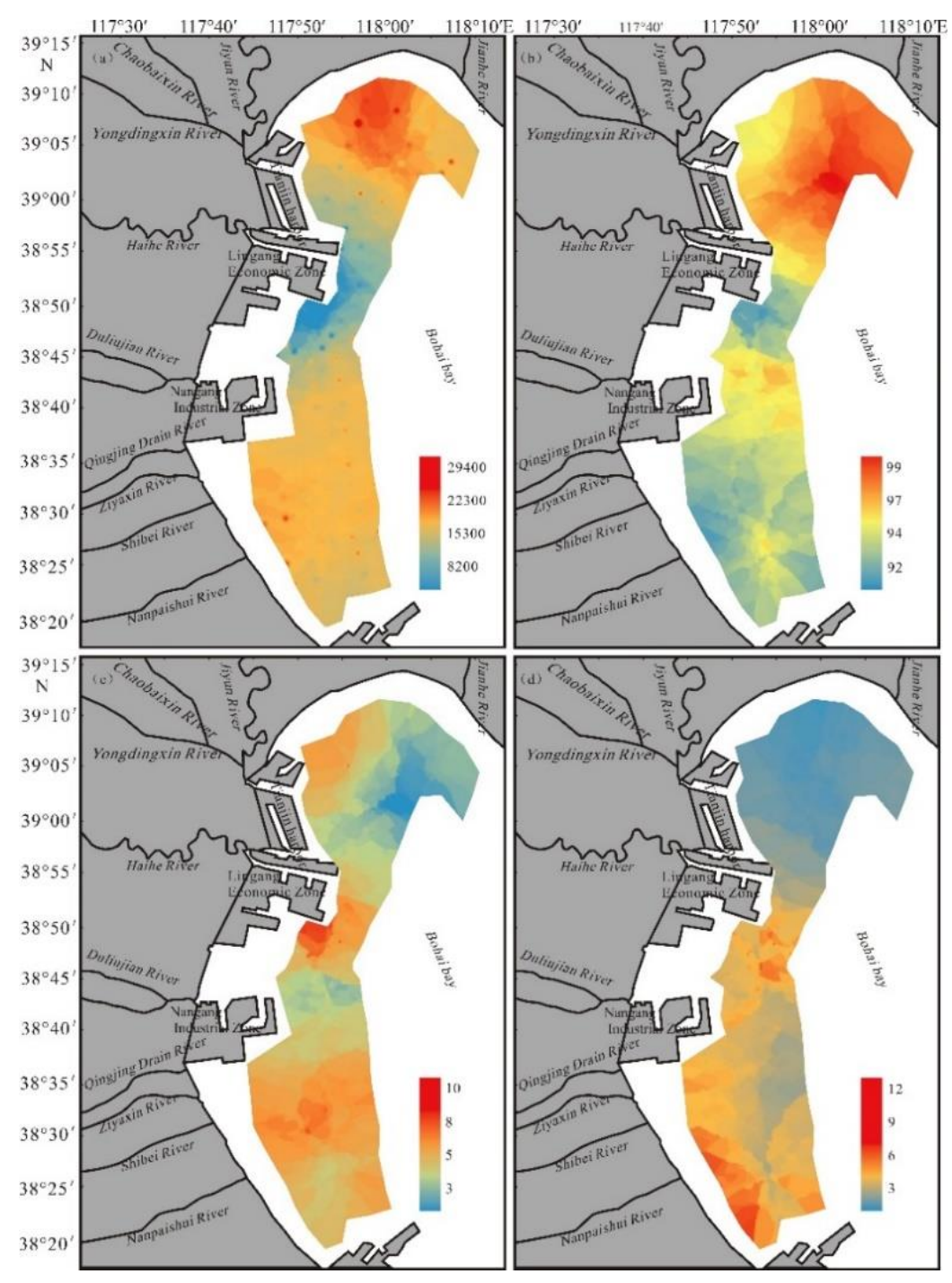

Figure 3. The distribution of saltwater, brackish water, freshwater species and Diatom abundance in the study area ( $a$-Diatom abundance; $b$ - content of saltwater diatoms; $c$ - content of brackish water diatoms; $d$ - content of freshwater diatoms)

The abundance of diatoms in the study area ranges from 800 to $30,600 / \mathrm{g}$, with an average of $12,979 / \mathrm{g}$. The diatoms in the bay north of the Haihe River estuary are the most abundant. Among the sample sites, the abundance of diatoms at stations $1-3,6-8$, $13-16,18-19$ and $21-22$ on the northwest shore reach $15,800-30,600 / \mathrm{g}$, which is higher than the average of the study area. Diatoms are second most abundant in the sea south of the Duliujian River estuary at 7,000-21,000/g. Diatom abundance in the sea 
between the Haihe River Estuary and the Duliujian River estuary is the lowest, with a range of 800-20,300/g.

Saltwater diatoms are distributed throughout the study area and have the highest proportion, with a proportion of $72.73 \%$ to $100.00 \%$. Saltwater diatoms have the highest proportion in the bay north of the Haihe River estuary, and the proportion from shore to sea direction increases. The proportion of saltwater diatoms in the sea south of the Haihe River estuary is lower than that in the bay north of the Haihe River estuary. Among the sea south of the Haihe River estuary, the stations in the waters adjacent to the Nangang Industrial Zone (stations 64, 71-72, 74-77, 79-81 and 83-87) have a high proportion of saltwater diatoms, ranging from $92.86 \%$ to $98.84 \%$. The proportion of saltwater diatoms in other stations is varied and ranges from $72.73 \%$ to $100.00 \%$.

The proportion of brackish water diatoms is $0.00 \%-19.70 \%$ in the study sea area. In the bay north of the Haihe River estuary, the proportion of brackish water diatoms tends to decrease from the shore to the sea. The proportion of brackish water diatoms in the western coastal waters of the bay (at stations 1, 6, 13, 14, 20, 21, 22, 27, 31, 32, and 35) is relatively high compared to the inner bay, with a proportion of $3.05 \%-12.37 \%$. The brackish water diatom proportion at the stations in the inner bay (stations 7-9, 11, 15$18,23-26,28,30,33-34$, and 36-39) is low, ranging from $0 \%$ to $1.98 \%$. In the sea south of the Haihe River estuary, the proportion of brackish water diatoms is relatively high in the southeastern sea area of the Lingang Economic Zone (stations 49, 50, 52, 55-57, 59-60, 65 and 70) and the sea south of the Nangang Industrial Zone, compared to the waters adjacent to the Nangang Industrial Zone, ranging from $3.77 \%$ to $19.7 \%$. The proportion of brackish water diatoms in the waters adjacent to the Nangang Industrial Zone (stations 66, 67, 68, 71, 75 and 80) is relatively small, ranging from $0 \%$ to $1.89 \%$.

The proportion of freshwater diatoms is $0.00 \%-13.13 \%$ in the study sea area. Freshwater diatoms are mainly distributed in the sea south of the Haihe River estuary, with a ratio of $0 \%$ to $13.13 \%$, and the proportion decreases from the shore to the sea. The proportion of freshwater diatoms in the sea south of the Shibei River estuary (stations 94-95, 97-98, 100-102, 106, 110-112, 115-117, 119, 122 and 125-126) is the highest, reaching $2.22 \%-13.13 \%$. Additionally, within that region, the proportion of freshwater diatoms shows a trend of initial decreases and subsequent increases from the shore to the sea. The freshwater diatom proportion in the sea area north of the Shibei River estuary decreased. The proportion of freshwater diatoms in the bay north of the Haihe River estuary is lowest, ranging from $0 \%$ to $2.14 \%$. No freshwater diatoms are found at stations 15, 16, 23, 29 and 34 in the inner bay.

\section{Discussion}

\section{Characteristics of diatom assemblages}

CA was used to analyse the characteristics of diatom assemblages. In the scatter plot of the main taxa in the CA (Fig. 4), the locational distribution of diatom species reflects the composition of the major diatom species. The closer the location of the distribution of species in the figure, the closer the relationship between diatom species. The Fig. 4 shows that the main diatom species are divided into four groups. Group I is the dominant species of diatoms, including Cosinodiscus excentricus, Cosinodiscus radiatus, Actinocyclus normanii, Actinocyclus senarius and Surirella fluminensis. The freshwater species, Synedra ulna and Nitzschia palea are also distributed throughout the study area. Group II is mainly brackish water diatoms, including Grammatophora macilenta, Diploneis suborbicularis, Nitzschia compressa, Tryblioptychus 
cocconeiformi, Rhopalodia gibberula, Actinoptychus annulatus and Auliscus caelatus, as well as the saltwater diatoms, Dictyocha fibula, Triceratium favus and Epithemia adanata. Group III includes Cyclotella striata, Trachyneis aspera and Paralla sulcata, as well as the brackish water species, Nitzschia granulata, and the freshwater species, Achnanthes hauckiana. Group IV is mainly saltwater diatoms, including Cyclotella stylorum, Thalassiosira nizschioides, Synedra tabulata, Ellerbeckia arenaria, Gyrosigma acuminatum, Nitzschia kerguelensis, Navicula clementis, Pleurosigma normanii, Navicula radiosa and Surirella fluminensis, as well as the brackish water species, Diploneis smithii, Rhaphoneis surirella, Diploneis Bombus and Rhizosolenia imbricata.

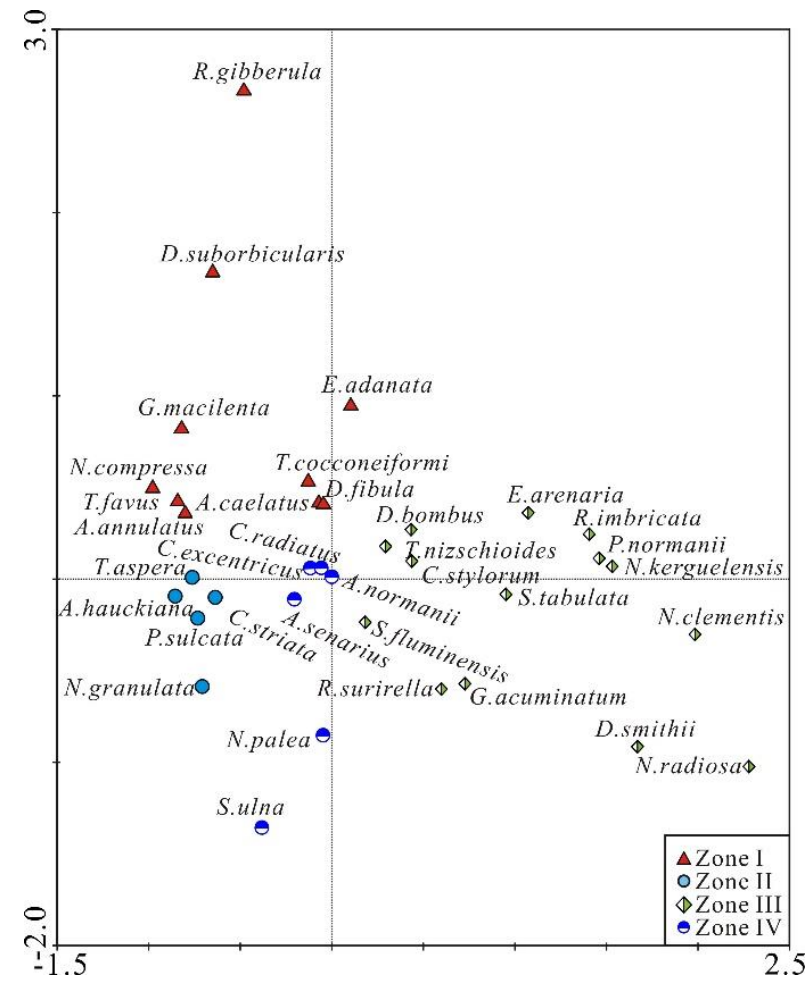

Figure 4. Scatter diagram of CA main taxa

Corresponding to the CA scatter diagram of diatom station (Fig. 5a), stations containing similar diatom species are distributed in adjacent locations. Therefore, the study area is divided into four diatom combination zone, according to the diatom combination division (Fig. 5b). Zone I includes stations 1-32, 34-35 and 38-39. Zone II includes stations 33, 36-37, 40-63 and 65-69. Zone III includes stations 64 and 70105. Zone IV includes stations 106-126.

Zone I is distributed in the bay north of the Haihe River estuary. The abundance of diatoms in Zone $\mathrm{I}$ is $6500-30600 \mathrm{/g}$, and the average abundance is $15417 \mathrm{/g}$. Cosinodiscus excentricus-Cosinodiscus radiates-Actinocyclus normanii is the dominant diatom combination, with a proportion of $79.67 \%$. The proportion of saltwater diatoms is $86.60 \%-99.48 \%$, and the average proportion is $96.44 \%$. Among the main saltwater species, Cyclotella striata, Cyclotella stylorum, Triceratium favus and Paralla sulcate are inner Bay indicator species (Kazuo and Kiyoshi, 1990; Chiba and Sawai, 2014), 
with a proportion of $9.47 \%$. Dictyocha fibula is seawater muddy intertidal indicator species (Kazuo and Kiyoshi, 1990; Chiba and Sawai, 2014), Thalassiosira nizschioides and Actinocyclus senarius are pelagic indicator species in the ocean (Kazuo and Kiyoshi, 1990; Chiba and Sawai, 2014), with a proportion of $2.94 \%$. The proportion of brackish water diatoms is $0 \%-12.30 \%$, with an average proportion of $2.92 \%$. Among the main brackish water species, Rhaphoneis surirella, Auliscus caelalus and Opephora martyi are seawater sandy intertidal indicators species (Kazuo and Kiyoshi, 1990; Chiba and Sawai, 2014), with a proportion of $0.78 \%$, Diploneis bombus is seawater muddy intertidal indicator species, with a proportion of $0.72 \%$. Tryblioptychus cocconeiformi is indicator species of the seaweed field (Kazuo and Kiyoshi, 1990; Chiba and Sawai, 2014), with a proportion of $0.11 \%$. Freshwater diatoms are found in the sea along the Yongdingxin River estuary and the Jian River estuary, ranging from $0.50 \%$ to $2.14 \%$. The main diatom species are Achnanthes hauckiana, Synedra ulna and Nitzschia palea. Among those species, Achnanthes hauckiana often appeares in the estuary, coastal waters, and land lakes (Hartley, 1996). Synedra ulna lives in eutrophic environments with a salinity of less than $2 \%$ (Chiba and Sawai, 2014). Nitzschia palea can survive in highly polluted and highly corrosive waters (Kosugi, 1988). Synedra tabulate, Ellerbeckia arenaria, Rhopalodia gibba, Eunotia valida and Epithemia adanata are also found at individual stations. Among those species, Eunotia valida lives in oligotrophic environments (Fontana et al., 2014).

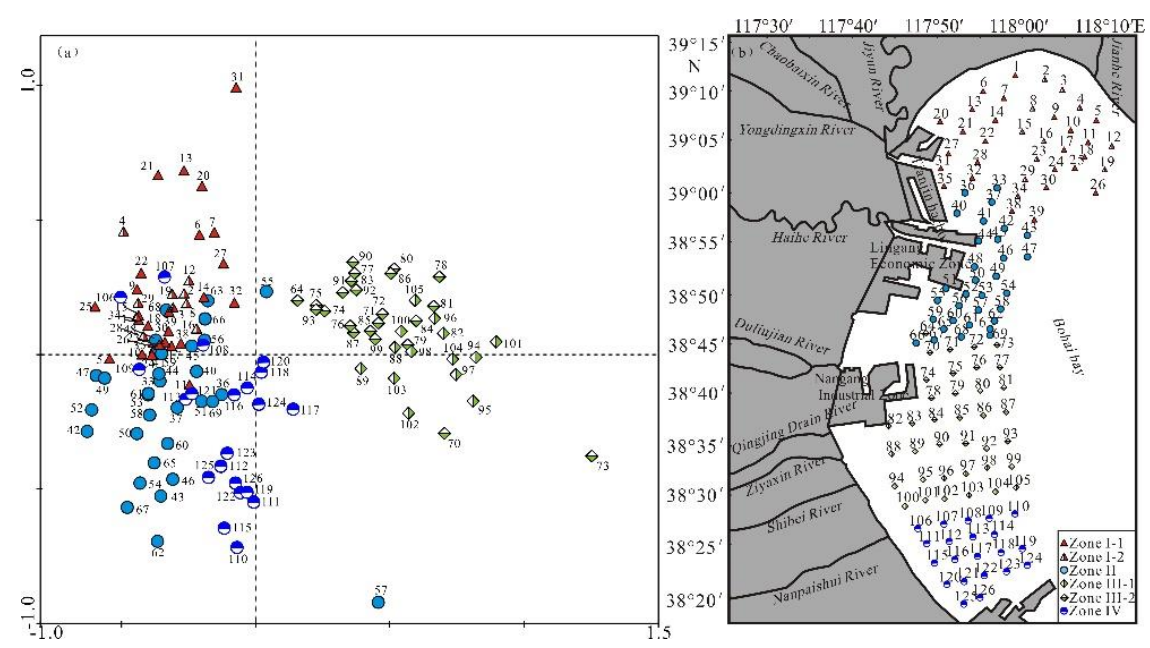

Figure 5. CA scatter diagram of diatom station and diatom combination zone in the study area (a: $C A$ scatter diagram of diatom station; $b$ : diatom combination zone)

The freshwater diatom proportion in the sea along the Yongdingxin River estuary is $0.56 \%-1.53 \%$, with a decreasing trend from south to north. The freshwater diatom proportion in the sea along the Jian River Estuary is $0.50 \%-2.14 \%$, with a decreasing trend from north to south. A total of 36 diatom species are found in zone I, with the most diversity and abundance in the four diatom combination zones. Because the tidal energy in the northwestern part of the bay is weak, and the barrier effect of the Luan River delta in eastern weakens the energy of the current (Pei et al., 2009). Thus, zone I is abundant in diatoms due to the suitable environment for their survival. According to the proportion of freshwater diatoms, zone I is divided into two sub-zones (I-1 zone and 
I-2 zone). The I-1 zone includes the sea along the Yongdingxin River estuary (stations 1, 6-7, 13-14, 20-22, 27-28, 31-32, 35 and 38-39) and the sea along the Jian River estuary (stations 5, 9-11, 17-18, 24-26 and 30). The proportion of saltwater diatoms in zone I-1 is relatively low, but the proportion of brackish water species is high. In the sea along the Yongdingxin River estuary, the proportion of brackish water diatoms is $0.68 \%-12.37 \%$, and the average proportion is $4.60 \%$, which is much higher than the average value of zone I. Freshwater diatoms are found in the zone I-1. Due to the influence of the two rivers entering the sea, the maritime nature of area I-1 is weak, and is influenced by the action of the river. Xu et al. (2008) found that there is a low-salt sea area near the intersection of the Yonghexin River and the Jiyun River. The lowest salinity value is $27.21 \%$ o (Xu et al., 2008), which is consistent with the trend in diatom species in zone I-1.

Zone I-2 is distributed in the inner bay (stations 2-4, 8, 12, 15-16, 19, 23, 29 and 34). The proportion of saltwater diatoms in zone I-2 is the highest in the overall study area, and no freshwater diatoms are found. Therefore, zone I-1 is an intertidal zone that is relatively strongly influenced by rivers, while zone I-2 is an inner bay that is not affected by rivers.

Zone II is mainly distributed in the sea between the Haihe River estuary and the Jian River estuary. The abundance of diatoms is the smallest, ranging from 800 to 21,000 /g, with an average abundance of $7,359 / \mathrm{g}$. Cosinodiscus excentricus-Cosinodiscus radiates-Actinocyclus normanii is the dominant diatom combination, with a proportion of $81.74 \%$. The proportion of saltwater diatoms is $72.73 \%-100.00 \%$, and the average proportion is $93.69 \%$, which is lower than that in Zone I. The main saltwater diatoms include the inner bay indicator species (Cyclotella striata, Cyclotella stylorum, Triceratium favus and Paralla sulcata), with a proportion of $9.11 \%$, and the pelagic indicator species (Thalassiosira nizschioides), with a proportion of $1.41 \%$. The proportion of brackish water diatoms is $0 \%-19.7 \%$, and the average proportion is $3.90 \%$, which is higher than that in zone I. The main brackish water diatoms include the seawater muddy intertidal indicator species (Diploneis bombus, Nitzschia granulata and Diploneis smithii), with a proportion of $0.97 \%$, and seawater sandy intertidal indicator species (Rhaphoneis surirella, Auliscus caelalus), with a proportion of $0.76 \%$. The proportion of freshwater diatoms ranges from $0 \%$ to $11.50 \%$, which are distributed throughout stations 33, 36-37, 40, 42-44, 46, 50-51, 54, 57-58, 60-63, 65, 67 and 69. The main freshwater diatoms are Synedra ulna, Achnanthes hauckiana, Melosira granulate and Gomphonema tumidum. A small amount of Epithemia adanata and Ellerbeckia arenaria is also discovered. The proportion of freshwater diatoms in stations $50-51,54,57,60,62$, and 67 reachs $7.68 \%$, which is higher than the average value in zone II.

Since 1967, the Duliujian River has contained a moisture barrier in the downstream estuary, causing serious silting of the river under the water barrier, and resulting in very low annual runoff, which has weakened the river's energy transfer to the sea. Thus, the impact of the Duliujian River on the proportion of freshwater diatoms in zone II is negligible. The sediments in zone II are mainly affected by the Haihe River (Tian et al., 2010; Han et al., 2011). Freshwater diatoms entering the sea are deposited by waves and tides, which are the main reasons for the high proportion of freshwater diatoms. Zone II is the least abundant zone among the three diatom combination zones, with a total of 24 species of diatoms found in zone II. Under the influence of the Haihe River, the salinity of the sea area is lower than that of the surrounding sea area. At the same time, the wave and tidal action of the sea area is dominated by hydrodynamic forces, and the sediments entering the sea are formed fine sand deposits during repeated waves and tides (Pei et al., 2010). Under complex hydrodynamic conditions, diatoms are not easy to preserve 
due to their friction with coarse particles, which is also the reason for the lowest abundance of diatoms in zone II. Therefore, zone II is an intertidal zone that is affected by rivers and tides.

Zone III is distributed in the sea between the Duliujian River estuary and the Nanpaishui River estuary. The abundance of diatoms is 10400-21000 /g, and the average abundance is $15005 / \mathrm{g}$. Cosinodiscus excentricus-Cosinodiscus radiatesActinocyclus normanii-Cyclotella stylorum is a dominant diatom combination, with a proportion of $84.82 \%$. The proportion of saltwater diatoms is $72.73 \%-100 \%$, and the average proportion is $93.69 \%$. The main saltwater diatoms include seawater muddy intertidal indicator species (Dictyocha fibula), which have a proportion of $4.67 \%$, and pelagic indicator species (Thalassiosira nizschioides and Actinocyclus senarius), which have a proportion of $4.39 \%$. The proportion of brackish water diatoms is $0.58 \%-$ $12.35 \%$, and the average proportion is $4.46 \%$. The main saltwater diatoms include seawater muddy intertidal indicator species (Diploneis bombus, Nitzschia granulata, Diploneis smithii and Nitzschia lorenziana), with a proportion of $2.67 \%$, seawater sandy intertidal indicator species (Rhaphoneis surirella, Auliscus caelalus and Dimeregramma minor), with a proportion of $1.48 \%$, and the indicator species of the seaweed field (Tryblioptychus cocconeiformi), with a proportion of $0.03 \%$. The proportion of freshwater diatoms ranges from $0.58 \%$ to $7.69 \%$ and is distributed in stations $70-91$, 94-98 and 100-105. Freshwater diatoms in zone III are the most diverse of the four combination zones, reaching 14 species. Additionally, the species of freshwater diatoms change, compared to the zone I and zone II. The main freshwater diatoms are Nitzschia palea, Ellerbeckia arenaria, Gyrosigma acuminatum and Pleurosigma normanii. Among those species, Ellerbeckia arenaria lives in eutrophic conditions (Fontana et al., 2014) and Gyrosigma acuminatum often lives in marsh environments (Chiba and Sawai, 2014; Chen, 2016). Pinnularia nobils lives in lakes with salinities of less than 2\%o (Zhang et al., 2012). Hantzschia amphioxys are freshwater species that live in alkaline environments (Kazuo and Kiyoshi, 1990; Kashima, 1992), and Gomphonema tumidum lives in swamp wetlands (Kazuo and Kiyoshi, 1990; Chiba and Sawai, 2014). Melosira granulate lives in eutrophic lakes (Jin, 1982; Kazuo and Kiyoshi, 1990; Kashima, 1992), while Nizschia amplectems lives in alkaline marsh wetlands (Kazuo and Kiyoshi, 1990; Kashima, 1992). Few Synedra tabulate, Epithemia adanata and Synedra ulna are found at individual stations.

According to the analysis of diatom combinations, zone III is divided into two sub-regions (regions III-1 and III-2). Zone III-1 includes stations 82, 88-89, 94-98 and 100-105, and locates along the Qingjing drain estuary, the Ziyaxin River estuary and the Shibei River estuary. The proportion of saltwater diatoms in Zone III-1 are the lowest in the study area, ranging from $84.57 \%$ to $95.52 \%$. The proportion of brackish water diatoms and freshwater species is relatively high compared to zone III-2, with a proportion of $2.05 \%-12.35 \%$ and $0.75 \%-4.82 \%$, respectively. Due to the influence of many rivers entering the sea, zone III-1 is strongly influenced by rivers, causing intense mixing of saltwater and freshwater. Thus, there is a low salinity sea area (Xu et al., 2008). Zone III-2 includes stations 64, 70-81, 83-87, 90-93 and 99, and is weakly affected by the river. The proportion of diatoms in saltwater in zone III-2 is higher than that in zone III-1, ranging from $86.89 \%$ to $98.84 \%$. The proportion of brackish water diatoms and freshwater diatoms decreases compared to zone III-1, with proportions of $0.58 \%-9.84 \%$ and $0 \%-7.69 \%$, respectively. Therefore, zone III-1 is an intertidal zone that is strongly affected by rivers. Zone III-2 is a subtidal zone that is weakly affected by rivers.

Zone IV is located in the sea south of the Nanpaishui River estuary and the zone includes stations 106-126. The abundance of diatoms is 7000-20600/g, and the average 
abundance is 13795 /g. Cosinodiscus excentricus-Cosinodiscus radiates-Actinocyclus normanii is a dominant diatom combination, with a proportion of $74.81 \%$. The proportion of saltwater diatoms is $78.79 \%-97.14 \%$, and the average proportion is 91.91\%. The main saltwater diatoms include the inner bay indicator species (Cyclotella striata, Cyclotella stylorum and Paralla sulcata), with a proportion of $10.51 \%$, pelagic indicator species in the ocean (Thalassiosira nizschioides and Actinocyclus senarius), with a proportion of $2.97 \%$, and seawater muddy intertidal indicator species (Dictyocha fibula), with a proportion of $1.09 \%$. The proportion of brackish water diatoms is $1.48 \%-$ $9.48 \%$, and the average proportion is $4.37 \%$, which is similar to that in zone III. The main brackish water diatoms include seawater sandy intertidal indicator species (Rhaphoneis surirella and Auliscus caelalus), with a proportion of $3.03 \%$, and seawater muddy intertidal indicator species (Diploneis bombus), with a proportion of $0.79 \%$. The freshwater diatoms in the zone IV accounte for the largest proportion, ranging from $0.65 \%$ to $13.17 \%$, and are distributed in stations 106-117, 119-123, 125 and 126. Freshwater diatoms mainly include Synedra ulna, Nitzschia palea and Gyrosigma acuminatum. Few Ellerbeckia arenaria, Pleurosigma normanii and Epithemia adanata are found at some of the stations. After freshwater diatoms enter the sea under the action of the river, a portion of freshwater diatoms are transported offshore by the inertia of the river, and another portion of freshwater diatoms migrate northward under the influence of coastal currents. We find that the proportion of saltwater diatoms in zone IV have a trend of increasing first and then decreasing from the coastal sea to the offshore. However, freshwater diatoms show the opposite trend. In the offshore (stations 108, $109,110,119$ and 122-123), the proportion of freshwater diatoms increases, ranging from $1.14 \%$ to $13.13 \%$, which are more than the coastal sea (stations 107, 118 and 120121), ranging from $0 \%-1.55 \%$. However, the species of freshwater diatoms in the offshore sea are similar to the species of freshwater diatoms in the nearshore sea. In addition to normal tidal hydrodynamics, the sea area is also affected by wind and waves on the shore (Pei et al., 2009), which is the reason for the changing trend of freshwater and saltwater diatoms. Therefore, zone IV is an intertidal-subtidal zone strongly affected by rivers.

The main diatom species and sedimentary environments in the study area are summarized in Table 1.

\section{The function of freshwater diatoms in the seawater flow pathway}

The distribution of freshwater diatoms is consistent with the diatom combination zones. The proportion of freshwater diatoms is the highest in zone IV, and the southern part of zone III (94-98, 100-117, 119-123, 125 and 126), ranging from $0.65 \%$ to $13.13 \%$. Under the influence of the river that flows into the sea, freshwater diatoms, such as Synedra ulna, Nitzschia palea, Ellerbeckia arenaria, Gyrosigma acuminatum, Pleurosigma normanii, Pinnularia nobils, Hantzschia amphioxys and Nizschia amplectems enter the sea. After freshwater diatoms enter the sea, some diatoms are transported offshore by the inertia of the river, and form a sedimentary trend perpendicular to the coastline, while another portion of the freshwater diatom move northward under the action of the current. 
Table 1. Dominant diatom assemblages, proportion of freshwater diatoms and deposition environment in study area

\begin{tabular}{|c|c|c|c|c|}
\hline $\begin{array}{c}\text { Zone } \\
\text { station }\end{array}$ & \begin{tabular}{|c|}
$\begin{array}{c}\text { Salt, brackish and } \\
\text { freshwater species } / \%\end{array}$ \\
\end{tabular} & Main diatoms assemblages $/ \%$ & Freshwater diatoms $/ \%$ & $\begin{array}{c}\text { Deposition } \\
\text { environment }\end{array}$ \\
\hline $\mathrm{I}-1$ & $\begin{array}{l}95.62 \\
3.46 \\
1.10\end{array}$ & $\begin{array}{c}\text { Cosinodiscus excentricus } \\
\text { (33.15),Cosinodiscus radiates } \\
\text { (27.30),Actinocyclus normanii } \\
\text { (18.09), Cyclotella striata } \\
\text { (5.19),Dictyocha fibula }(3.14) \\
\end{array}$ & $\begin{array}{c}\text { Nitzschia palea }(0.40), \\
\text { Achnanthes hauckiana } \\
(0.30), \text { Synedra ulna } \\
(0.12)\end{array}$ & $\begin{array}{c}\text { intertidal zone } \\
\text { relatively strongly } \\
\text { influenced by } \\
\text { rivers }\end{array}$ \\
\hline $\mathrm{I}-2$ & $\begin{array}{c}98.31 \\
1.69 \\
0\end{array}$ & $\begin{array}{c}\text { Cosinodiscus excentricus } \\
\text { (38.49), Cosinodiscus radiate } \\
(22.89), \text { Actinocyclus normanii } \\
\text { (20.85), Cyclotella striata } \\
\text { (4.44),Dictyocha fibula }(3.47) \\
\end{array}$ & not found & $\begin{array}{l}\text { inner bay not } \\
\text { affected by rivers }\end{array}$ \\
\hline II & $\begin{array}{c}93.69 \\
3.90 \\
3.86\end{array}$ & \begin{tabular}{|c|} 
Cosinodiscus excentricus \\
(39.89),Cosinodiscus radiates \\
(23.27),Actinocyclus normanii \\
(18.58), Cyclotella striata \\
$(3.47)$, Nitzschia granulata (1.57) \\
\end{tabular} & $\begin{array}{c}\text { Nitzschia palea }(2.49), \\
\text { Synedra ulna }(0.86), \\
\text { Achnanthes hauckiana } \\
(0.14)\end{array}$ & $\begin{array}{l}\text { intertidal zone } \\
\text { affected by rivers } \\
\text { and tides }\end{array}$ \\
\hline III-1 & $\begin{array}{c}91.36 \\
5.58 \\
3.06\end{array}$ & $\begin{array}{c}\text { Actinocyclus normanii } \\
\text { (28.56), Cosinodiscus radiates } \\
\text { (19.63), Cosinodiscus excentricus } \\
\text { (19.08), Cyclotella stylorum } \\
\text { (13.94),Thalassiosira nizschioides } \\
\text { (5.32) }\end{array}$ & $\begin{array}{l}\text { Pleurosigma normanii } \\
(0.93), \text { Gyrosigma } \\
\text { acuminatum }(0.72), \\
\text { Nitzschia palea }(0.60)\end{array}$ & $\begin{array}{c}\text { intertidal zone very } \\
\text { strongly affected } \\
\text { by rivers }\end{array}$ \\
\hline III-2 & $\begin{array}{l}94.22 \\
3.78 \\
2.49\end{array}$ & $\begin{array}{c}\text { Actinocyclus normanii } \\
\text { (27.58),Cosinodiscus radiates } \\
\text { (26.95),Cosinodiscus excentricus } \\
\text { (22.90),Cyclotella stylorum } \\
\text { (9.83),Thalassiosira nizschioides } \\
\text { (3.04) } \\
\end{array}$ & $\begin{array}{c}\text { Ellerbeckia arenaria } \\
(1.26), \text { Gyrosigma } \\
\text { acuminatum }(0.31), \\
\text { Nitzschia palea }(0.28)\end{array}$ & $\begin{array}{c}\text { subtidal zone } \\
\text { weakly affected by } \\
\text { rivers }\end{array}$ \\
\hline IV & $\begin{array}{c}91.91 \\
4.37 \\
4.12\end{array}$ & \begin{tabular}{|c|} 
Actinocyclus normanii \\
(27.54),Cosinodiscus radiates \\
(26.12),Cosinodiscus excentricus \\
(21.15), Cyclotella striata \\
(5.24),Cyclotella stylorum (2.82)
\end{tabular} & $\begin{array}{c}\text { Nitzschia palea }(2.51), \\
\text { Synedra ulna }(1.05), \\
\text { Gyrosigma acuminatum } \\
(0.44)\end{array}$ & $\begin{array}{l}\text { intertidal-subtidal } \\
\text { zone strongly } \\
\text { affected by rivers }\end{array}$ \\
\hline
\end{tabular}

The proportion of freshwater diatoms in the central and northern stations of zone III (74-91) decrease, ranging from $0.58 \%$ to $7.69 \%$. Compared with the southern sea, the proportion of Nitzschia palea, Ellerbeckia arenaria, Gyrosigma acuminatum, and Pleurosigma normanii are decreased, while Synedra ulna is not observed in the sea. The proportion of freshwater diatoms in zone II (stations 40, 42-44, 46, 50-51, 54, 57-58, $60-63,65,67$ and 69-73) increases, ranging from $0.48 \%$ to $11.5 \%$. The species of freshwater diatoms in zone II have changed, compared to zone III and zone IV; Pleurosigma normanii is not observed in the sea, while Melosira granulate, Gomphonema tumidum, and Synedra ulna, albeit in low proportions. The proportion of the freshwater diatoms, Nitzschia palea, Ellerbeckia arenaria, and Gyrosigma acuminatum increases, especially in stations 50-51, 54, 57, 60, 62, and 67, reachs $7.68 \%$, which is higher than the regional average in Zone II.

Since 1967, the Duliujian River has contained a moisture barrier in the downstream estuary, causing serious silting of the river under the gate, and resulting in very small annual runoffs, and a weakening the river's water flow to the sea. Thus, the impact of the Duliujian River on the proportion of freshwater diatoms in zone II is negligible. The increase in freshwater diatom proportion in zone II is mainly affected by the land reclamation project along the Haihe River estuary. Due to the construction of the Lingang Economic Zone, the hydrodynamic conditions in the sea near the Haihe River 
estuary have been changed. At high tide, the flow rate in the southeastern side of the Lingang Economic Zone increased due to local flow, while during ebb tides, the flow rate in the southeastern side of the Lingang Economic Zone is reduced significantly. Therefore, sediments from the Haihe River are deposited, causing changes in the substrate (Nie and Tao, 2008). Also, due to the impact of the reclamation project on coastal currents, the deposition of freshwater diatoms increased in zone II. The freshwater diatoms in zone I are distributed in the sea along the Yongdingxin River Estuary and the Jian River Estuary. The main diatom species are Achnanthes hauckiana, Synedra ulna, Nitzschia palea and Ellerbeckia arenaria. Freshwater diatoms in the sea along the Yongdingxin River estuary (stations 1, 7, 14, 20, 22, 27-28, 31-32, 35 and 38-39) ranges from $0.56 \%$ to $1.53 \%$, and shows a downward trend from south to north. The freshwater diatom proportion in the sea along the Jian River Estuary (stations 5, 9$11,17-18,24-26$ and 30 ) is $0.50 \%-2.14 \%$. The diatom species are similar to those in the waters along the Yongdingxin River estuary, and shows a decreasing trend in proportion from north to south.

In summary, the changes in the proportion of freshwater diatoms indicated the flow of seawater in the study area (Figure 6). In the summer, the current flows from south to north in the sea south of the Diujian River estuary. Due to the influence of the Haihe River flowing into the sea and the influence of the land reclamation project on the tide and currents from the Duliujian River estuary to the Haihe River estuary, the hydrodynamic conditions of the sea have changed. In the bay north of the Haihe River estuary, the current flows from south to north along the west coast, then the coastal current flows along the north coast, and then flows to the southeast, a clockwise water current is formed.

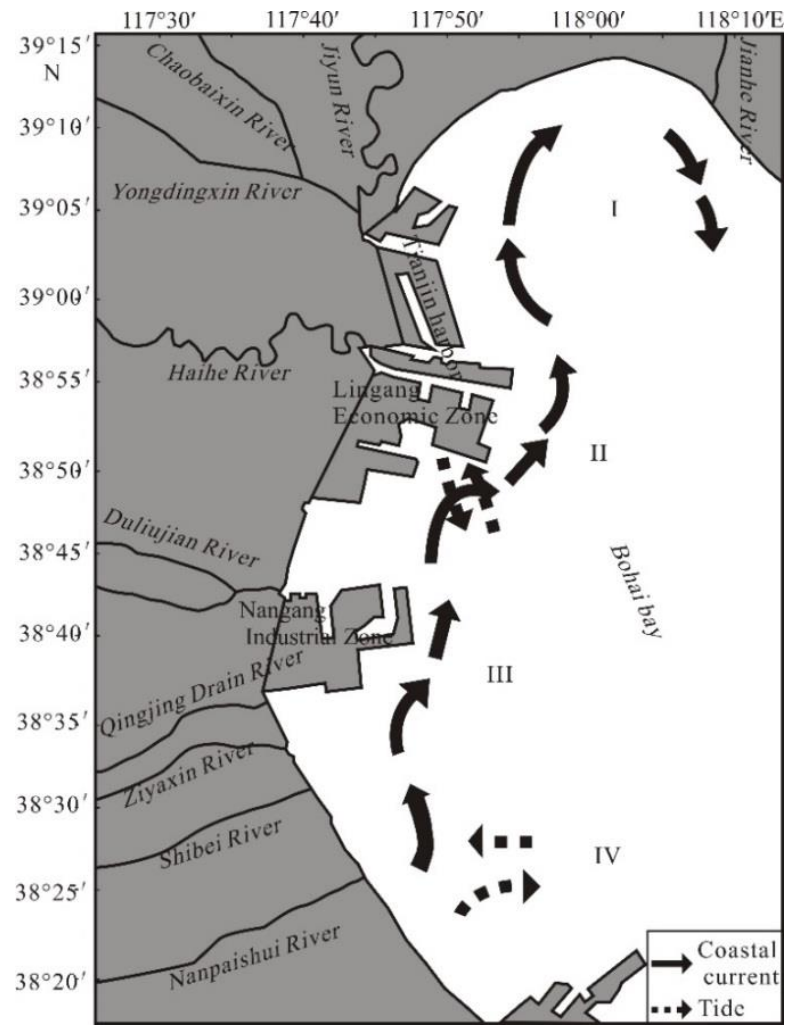

Figure 6. Freshwater diatom moving direction 


\section{Conclusions}

According to the diatom combinations of surface sediments in the inshore waters of the western Bohai Bay and the distribution of freshwater diatoms, the following results and conclusions are obtained:

(1) A total of 49 species and varieties of diatoms from 32 genera are identified in the study area. Four dominant species are found, and all of which are saltwater species, including Cosinodiscus excentricus, Cosinodiscus radiatus, Actinocyclus normanii and Cyclotella stylorums. Diatom abundance in the bay north of the Haihe River estuary is the highest, while diatom abundance in the sea south of the Duliujian River estuary is the second. Diatom abundance in the sea between the Haihe River Estuary and the Duliujian River estuary is the lowest and is affected by the flow of the Haihe River, as well as tides.

(2) All 126 stations are dominated by saltwater diatoms. Saltwater diatoms have the highest proportion in the bay north of the Haihe River estuary. The proportion of saltwater diatoms in the sea south of the Haihe River estuary is lower than that in the bay north of the Haihe River estuary. The brackish water diatoms are mainly distributed in the Yongdingxin River estuary, the sea southeast of the Lingang Economic Zone and the sea south of the Nangang Industrial Zone. In the bay north of the Haihe River estuary, the proportion of brackish water diatoms tend to decrease from the shore to the sea. Freshwater diatoms are found at 93 stations with a proportion of $0.48 \%$, and are regularly distributed in the study area.

(3) According to the diatom combination analyses, the study area is divided into four sedimentary areas. Zone I is distributed in the bay north of the Haihe River estuary and is divided into an intertidal zone (I-1 zone), which is strongly influenced by rivers, and the Inner Bay zone (I-2 zone), which is not affected by rivers. Zone II is distributed in the sea between the Haihe River estuary and Duliujian River estuary. It is an intertidal zone affected by the Haihe River, tides, and tidal currents. Zone III is distributed in the sea between the Duliujian River estuary and the Nanpaishui River estuary. It is divided into the intertidal zone (III-1), which is strongly influenced by rivers, and the subtidal zone (III-2), which is weakly affected by rivers. Zone IV is distributed in the sea south of the Nanpaishui River estuary. It is an intertidal-tidal zone that is strongly influenced by rivers.

(4) Trends in the distribution and abundance of freshwater diatoms in the inshore waters of the western Bohai Bay indicates that the land reclamation project on the west coast of the Bohai Bay affects the tide and water current, which changes the sediment transport direction. In the summer, the currents move from south to north in the sea south of the Haihe River estuary. The construction of the Lingang Economic Zone has changed the hydrodynamic conditions of the local waters, causing the rivers to enter the sea form sedimentary areas in the southeastern waters of the Lingang Economic Zone. In the bay north of the Haihe River estuary, a clockwise water current is formed.

(5) In this paper, we discussed the diatoms assemblage and the seawater flow pathway in summer. In future research we will investigate about whether the diatom assemblage changes with the season and freshwater could reflect the seawater flow pathway in winter.

Acknowledgements. This research was financially supported by the China geological survey program (DD20189506) and Tianjin Natural Science Foundation (18JCYBJC91100). 


\section{REFERENCES}

[1] Artemova, A. V., Sattarova, V. V., Vasilenko, Y. P. (2018): Distribution of diatoms and geochemical features of holocene sediments from the Kuril Basin (Sea of Okhotsk). Deep Sea Research Part II: Topical Studies in Oceanography 154: 10-23.

[2] Bennion, H. (1994): A diatom-phosphorus transfer function for shallow, eutrophic ponds in southeast England. - In: Mortensen, E., Jeppesen, E., Sondergaard, M., Kamp Nielsen, L. (eds.) Nutrient Dynamics and Biological Structure in Shallow Freshwater and Brackish Lakes: 391-410. Springer, Dordrecht.

[3] Cárdenas, P., Lange, C. B., Vernet, M., Esper, O., Srain, B., Vorrath, M. E., Ehrhardt, S., Müller, J., Kuhn, G., Arz, H. W., Lembke-Jene, L., Lamy, F. (2019): Biogeochemical proxies and diatoms in surface sediments across the Drake Passage reflect oceanic domains and frontal systems in the region. - Progress in Oceanography 174: 72-88.

[4] Chen, H. Y., Huh, C. A., Chang, N. Y., Chen, J. C. (2000): Sources and Distribution of Heavy Metals in East China Sea Surface Sediments. - Chemistry \& Ecology 17(3): 227238.

[5] Chen, M., Chen, C., Lan, B. B., Lan, D. Z., Qi, H. S. (2014): Diatom Assemblages and Distribution in Coastal Surface Sediments in the China Sea (Bohai Sea and Huanghai Sea). - Transactions of Oceanology and Limnology 33(2): 183-190.

[6] Chen, H. (2016): Sediment Diatom in Fresh Water. - Chemical Industry Press, Beijing.

[7] Chen, M., Li, Y. H., Qi, H. S., Wang, L., Zhang, A. M., Shen, L. N., Fang, Q. (2019): The influence of season and Typhoon Morakot on the distribution of diatoms in surface sediments on the inner shelf of the East China Sea. - Marine Micropaleontology 146: 5974.

[8] Chiba, T., Sawai, Y. (2014): Reexamination and updating of diatom species for paleoenvironmental reconstructions. - Diatom 30 (Supplement): 14-30.

[9] Cunningham, W. L., Leventer, A. (1998): Diatom assemblages in surface sediments of the Ross Sea: relationship to present oceanographic conditions. - Antarctic Science 10(2): 134-146.

[10] Ding, X. G., Ye, S. Y., Laws, E. A., Mozdzer, T. J., Yuan, H. M., Zhao, G. M., Yang, S. X., He, L., Wang, J. (2019): The concentration distribution and pollution assessment of heavy metals in surface sediments of the Bohai Bay, China. - Marine pollution bulletin 149: 110497.

[11] Fontana, L., Albuquerque, A. L. S., Brenner, M., Bonotto, D. M., Sabaris, T. P., Pires, M. A., Cotrim, M. E., Bicudo, D. C. (2014): The eutrophication history of a tropical water supply reservoir in Brazil. - Journal of Paleolimnology 51(1): 29-43.

[12] Hall, R. I., Smol, J. P. (2010): A weighted-averaging regression and calibration model for inferring total phosphorus concentration from diatoms in British Columbia (Canada) lakes. - Freshwater Biology 27(3): 417-434.

[13] Han, Z. Z., Zhang, J. Q., Zou, H., Yi, W. H., Li, M. (2011): Characteristics and Provenance of Clay Mineral Assemblage of Sediments from the Northern Part of the Bohai Bay. - Periodical of Ocean University of China (Natural Science Edition) 41(11): 95-102.

[14] Hartley, B. (1996): An Atlas of British Diatoms. - Biopress, Bristol.

[15] Hay, M. B., Pienitz, R., Thomson, R. E. (2003): Distribution of diatom surface sediment assemblages within Effingham Inlet, a temperate fjord on the west coast of Vancouver Island (Canada). - Marine Micropaleontology 48(3-4): 291-320.

[16] Hendey, N. I., Part, V. (1964): Bacillariophyceae (Diatoms in an introductory account of the smaller algae of British coastal waters. - Fishery investigation Series, IV London, 317. 
[17] Institute of Marine Geology, Institute of Oceanology, Chinese Academy of Sciences (1985): Bohai Geology. - Science Press, Beijing.

[18] Jin, D. X. (1982): Marine benthic diatoms in China (upper). - Shanghai Scientific \& Technical Publishers, Shanghai.

[19] Karpuz, N. K., Schrader, H. (1990): Surface sediment diatom distribution and Holocene paleotemperature variations in the Greenland, Iceland and Norwegian Sea. Paleoceanography 5(4): 557-580.

[20] Kashima, K. (1992): Catalog of Holocene diatom fossil part 1, Tokoro Plain, Hokkaido, North Japan. - The Geological Research Reports of Kyushu University, College of General Education 29: 1-36.

[21] Kazuo, A., Kiyoshi, F. (1990): Paleo-Environmental History and Sea-Level Records Based on the Diatom Assemblages in the Middle Part of the Arakawa Lowland, Central Japan. - The Quaternary Research 29(5): 427-437.

[22] Kosugi, M. (1988): Classification of living diatom assemblages as the indicator of environments, and its application to reconstruction of paleoenvironments. - The Quaternary Research (Daiyonki-Kenkyu) 27(1): 1-20.

[23] Leroy, S. A. G., Chalie, F., Wesselingh, F. P., Sanjani, M. S., Lahijani, H. A. K., Athersuch, J., Struck, U., Plunkett, G., Reimer, P. J., Habibi, P., Kabiri, K., Haghani, S., Naderi-Beni, A., Arpe, K. (2018): Multi-proxy indicators in a Pontocaspian system: a depth transect of surface sediment in the SE Caspian Sea. - Geologica Belgica 21: 143165 .

[24] Li, Q. X., Tao, J. H. (2000): Studies on Ecological Characteristics of Phytoplankton in the Waters Near Tianjin. - Journal of Tianjin University 4: 464-469.

[25] Liu, D., Liu, L., Di, B., Wang, Y. J., Wang, Y. N. (2015): Paleoenvironmental analyses of surface sediments from the Bohai Sea, China, using diatoms and silicoflagellates. Marine Micropaleontology 114: 46-54

[26] Nave, S., Freitas, P., Abrantes, F. (2001): Coastal upwelling in the Canary Island region: spatial variability reflected by the surface sediment diatom record. - Marine Micropaleontology 42(1): 1-23.

[27] Nie, H. T., Tao, J. H. (2008): Impact of coastal exploitation on the eco-environment of Bohai Bay. - The Ocean Engineering 26(3): 44-50.

[28] Pan, L., Fang, J., Tian, L. Z., Wang, F. (2019): Water Migration Pathway Based on Freshwater Diatoms in Sea Area Adjacent to the Nangang Industrial Zone of Tianjin. Journal of Coastal Research 93(sp1): 232-240.

[29] Pei, Y. D., Wang, Y. S., Fan, C. F., Wang, F., Tian, L. Z., Shang, Z. W., Che, J. Y., Wang, H. (2009): The surface sediment types and distribution of Tianjin intertidal zone, China. - Geological Bulletin of China 7: 915-922.

[30] Pei, Y. D., Tian, L. Z., Wang, F., Wang, H. (2010): Causation of the Fine Sandy Intertidal Zone on the West Coast of Bohai Bay. - Geological Survey and Research 3: 180-184.

[31] Perez, L., Brugnoli, E., Muniz, P., Sunesen, I., Sar, E. A., Crisci, C., Cuña, C., GarcíaRodríguez, F. (2018): Diatom assemblages from surface sediments of the Río de la Plata estuary, Uruguay. - New Zealand journal of marine and freshwater research 52(3): 383397.

[32] Ran, L., Jiang, H. (2005): Distributions of the surface sediment diatoms from the South China Sea and their palaeoceanographic significance. - Acta Micropalaeontologica Sinica 22(1): 97-106.

[33] Renberg, I. (1990): A procedure for preparing large sets of diatom slides from sediment cores. - Journal of Paleolimnology 4(1): 87-90.

[34] Shang, Z. W., Wang, H., Che, J. Y., Tian, L. Z., Pei, Y. D., Fan, C. F., Wang, F., Liu, Z. G. (2006): Diatom assemblages in the surface sediments of Bohai Bay. - Marine Geology \& Quaternary Geology 26(5): 21-26. 
[35] Shang, Z. W., Tian, L. Z., Wang, H., Li, J. F. (2012): Diatom assemblages from surficial sediments in north-central Bohai Bay and their implications for environments. - Geology in China 39(4): 1099-1107.

[36] Shen, G. Y., Shi, B. Z. (2002): Marine ecology. - Science Press, Beijing.

[37] Smol, J. P., Birks, H. J., Last, W. M. (2001): Tracking environmental change using lake sediments. - Springer Netherlands, Berlin.

[38] Tian, L. Z., Geng, Y., Pei, Y. D., Shang, Z. W., Wang, F., Fan, C. F., Wang, H. (2010): The grain-size characteristics and sediment mixing pattern of surface sediment from the western Bohai Bay, China. - Geological Bulletin of China 29(5): 668-674.

[39] Tian, L. Z., Pei, Y. D., Shang, Z. W., Wang, F., Wang, H. (2010): Elements Characteristics of the Suspended Component in Surface Sediments from the West Bohai Bay and the Provenance Implication. - Marine Geology \&Quaternary Geology 1: 9-15.

[40] Tu, J., Bai, Y. C., Xu, H. Y. (2017): Change of Coastline and Tidal Current Caused by Boahi Bay Reclamation Project. - Port Engineering Technology 8(4): 1-4.

[41] Wang, K. F., Jiang, H., Zhi, C. Y., Tao, M. H., Wang, H. G. (2001): Study on the relationship between diatom assemblage in surface sediments and the environment in the east China sea. - Acta Micropalaeontologica Sinica 18: 379-384.

[42] Wang, W., Li, A. C., Xu, F. J., Huang, P., Li, Y. (2009): Distribution of surface sediments and sedimentary environment in the North Yellow Sea. - Oceanologia et Limnologia Sinica/Hai Yang Yu Hu Chao 40(5): 525-531.

[43] Wang, H., Shang, Z. W., Li, J. F., Pei, Y. D., Wang, F., Tian, L. Z., Fan, C. F., Sheng, J. J., Chen, Y. S., Liu, H. M. (2010): Holocene shoreline changes and marine impacts on the muddy coast, western Bohai Bay, China. - Geological Bulletin of China 29(5): 627-640.

[44] Weckström, K., Juggins, S. (2006): Coastal diatom-environment relationships from the Gulf of Finland, Baltic sea. - Journal of Phycology 42(1): 21-35.

[45] Wu, R., Gao, Y. H., Fang, Q., Chen, C. P., Lan, B. B., Sun, L., Lan, D. Z. (2013): Diatom assemblages in surface sediments from the South China Sea as environmental indicators. - Chinese Journal of Oceanology and Limnology 31(1): 31-45.

[46] Xu, H. F., Jiang, B., Wu, H. (2008): China's offshore marine comprehensive adjustment and evaluation (908 special). - Tianjin 908 special physical ocean survey report.

[47] Xu, S. S., Di, B. P., Wang, Y. J., Liu, D. Y., Wang, X. D. (2017): Spatial distribution of benthic diatom in the typical intertidal zones in China. - Acta Oceanologica Sinica 39(6): 95-113.

[48] Zhang, C. J., Zhang, W. Y., Fan, R., Gao, D. (2012): Early diagenesis impacting C/N and organic isotopic compositions in the lacustrince sediments. - Journal of Earth Environment 3(4): 1005-1012.

[49] Zhao, B. R., Zhuang, G. W., Cao, D. M., Lei, F. H. (1995): Circulation tidal residual currents and their effects on the sedimentions in the Bohai Bay. - Oceanologia et Limnologia sinica 26(5): 466-473. 